We use cookies to broadly understand traffic to this website. Continue browsing if this is acceptable. Learn more about cookies

I understand

migrationpolicy.org

Published on migrationpolicy.org (https://www.migrationpolicy.org)

Home > Canada's Private Sponsorship Model Represents a Complementary Pathway for Refugee Resettlement

\title{
Canada's Private Sponsorship Model Represents a Complementary Pathway for Refugee Resettlement
}

\section{July 9, 2021 FEATURE | By lan Van Haren}

Canada is well known for its commitment to refugee resettlement. In 2018 and 2019, as the United States pulled back from its historic leading position, Canada resettled more refugees than any other country. Since the late 1970s, more than 770,000 refugees have been resettled to Canada. In contrast, the United States, with a population nearly nine times greater, has resettled about 3.5 million refugees since 1975 .

The Canadian government has relied heavily on private and nonprofit groups for much of this resettlement. In fact, since 2013 more refugees have arrived in Canada via private sponsorship than through government support. In 2019, just one-third of refugees resettled in Canada received government assistance upon arrival; the rest entered through private or community sponsorship.

Canada has the world's longest-standing private sponsorship program and, in part due to its success, other governments and agencies including the UN High Commissioner for Refugees (UNHCR) have come to see this as a promising model to increase refugee resettlement. In recent years, countries including Argentina, Australia, France, Germany, New Zealand, and Spain have undertaken or committed to similar programs. These initiatives take a variety of forms, but the central ingredient is that some degree of responsibility for refugees-particularly as it pertains to helping them settle into their new society-is transferred from the government to private citizens and civil-society groups.

At present, Canada has three programs for refugee resettlement: the Government Assisted Refugee (GAR) program, the Private Sponsorship of Refugees (PSR) program, and the Blended Visa-Office Referred (BVOR) program (see Table 1). In the PSR and BVOR programs, small groups of Canadians are involved in sponsoring refugees for resettlement. Through these sponsorship programs, which were established in 1976 and 2013, respectively, more than 368,000 refugee sponsorships have been facilitated, comprising about 48 percent of all refugees resettled to Canada since the late 1970 .

\section{Table 1. Refugee Resettlement Programs in Canada}




\begin{tabular}{|l|r|r|}
\hline \multicolumn{1}{|c|}{ Program } & $\begin{array}{c}\text { Organization Responsible for } \\
\text { Identifying Refugee }\end{array}$ & $\begin{array}{r}\text { Organization Responsible for Supporting } \\
\text { Refugee after Resettlement in Canada }\end{array}$ \\
\hline $\begin{array}{l}\text { Government Assisted } \\
\text { Refugee (GAR) Program }\end{array}$ & UNHCR or similar agency & Canadian government \\
\hline $\begin{array}{l}\text { Privately Sponsored } \\
\text { Refugee (PSR) Program }\end{array}$ & Sponsorship group & Sponsorship group \\
\hline $\begin{array}{l}\text { Blended Visa Office- } \\
\text { Referred (BVOR) Program }\end{array}$ & UNHCR or similar agency & $\begin{array}{r}\text { Sponsorship group and Canadian } \\
\text { government }\end{array}$ \\
\hline
\end{tabular}

Note: For all three programs, each refugee's application must be approved by Canadian government officials who ensure the applicant meets legal requirements.

Source: Author's compilation.

Sponsorship groups must be able to financially provide for refugees and are either limited in how many sponsorships they can submit each year or can only sponsor individuals with proof of refugee status. Some organizations have criticized these restrictions for excluding some forcibly displaced people from eligibility.

This article introduces Canada's resettlement system, with a focus on private sponsorship. It begins with a brief overview of refugee resettlement to Canada, describes how refugees are sponsored for resettlement, and concludes with a brief examination of the different integration outcomes of refugees resettled via government and private programs.

\section{A Brief History of Refugee Resettlement in Canada}

Canada's current refugee resettlement system is rooted in the country's 1976 Immigration Act. While there were some specific initiatives to assist refugees before this time, the law created distinct legal pathways for refugee resettlement. Soon after, in 1979-80, Canadians responded to assist Southeast Asian refugees, resettling more than 60,000. The government encouraged community sponsorship and volunteers eagerly became involved in local initiatives. During this period, 57 percent of Southeast Asian refugees were sponsored by private groups or relatives, and 43 percent were assisted by the government.

At first, most privately sponsored refugees were unknown to the groups assisting them. However, once new families arrived, they asked organizations to also sponsor their relatives and friends. Thus began the principle of "naming," in which sponsor groups identify individual refugees they hope to assist. Initially, sponsorship groups were usually affiliated with Catholic, Jewish, or Protestant denominational offices or organizations. Over time, an increasingly diverse group of organizations has become involved.

Implementation of the 1976 law created two refugee resettlement programs: the PSR program in which groups can name the refugees they want to support, and the GAR program in which UNHCR or a similar organization identifies who will be resettled and the Canadian government provides postarrival assistance. The different sources of support indicate who is responsible for assisting refugees during their first 12 months in Canada; after the initial year, any continued social assistance comes from the provincial government. The federal government's Interim Federal Health Program covers health-care expenses of all resettled refugees until they become eligible for provincial health-care programs. 
Since 2013, a third program has been available-the BVOR program-in which private groups sponsor refugees proposed for resettlement by UNHCR. Unlike the PSR naming principle, through this blended pathway UNHCR proposes which refugees need assistance and, once they are vetted by visa offices overseas, groups in Canada select whom they will assist from a bank of profiles. This program builds on pilot projects in the 1990 s and 2000 s that combined aspects of the GAR and PSR programs, and is like the initial PSR program before the naming principle became common. Although the blended program was relatively popular when the country raced to resettle 25,000 Syrian refugees in 2016, when it was used to resettle nearly 10 percent of refugees, the government has struggled recently to find willing sponsors for refugees they do not know.

The number of refugees resettled in Canada has varied over time as the government annually adjusts its target number of arrivals for each of the three resettlement programs (see Figure 1). Interest in submitting sponsor applications has also fluctuated.

Figure 1. Number of Refugees Resettled in Canada by Resettlement Program, 19792019

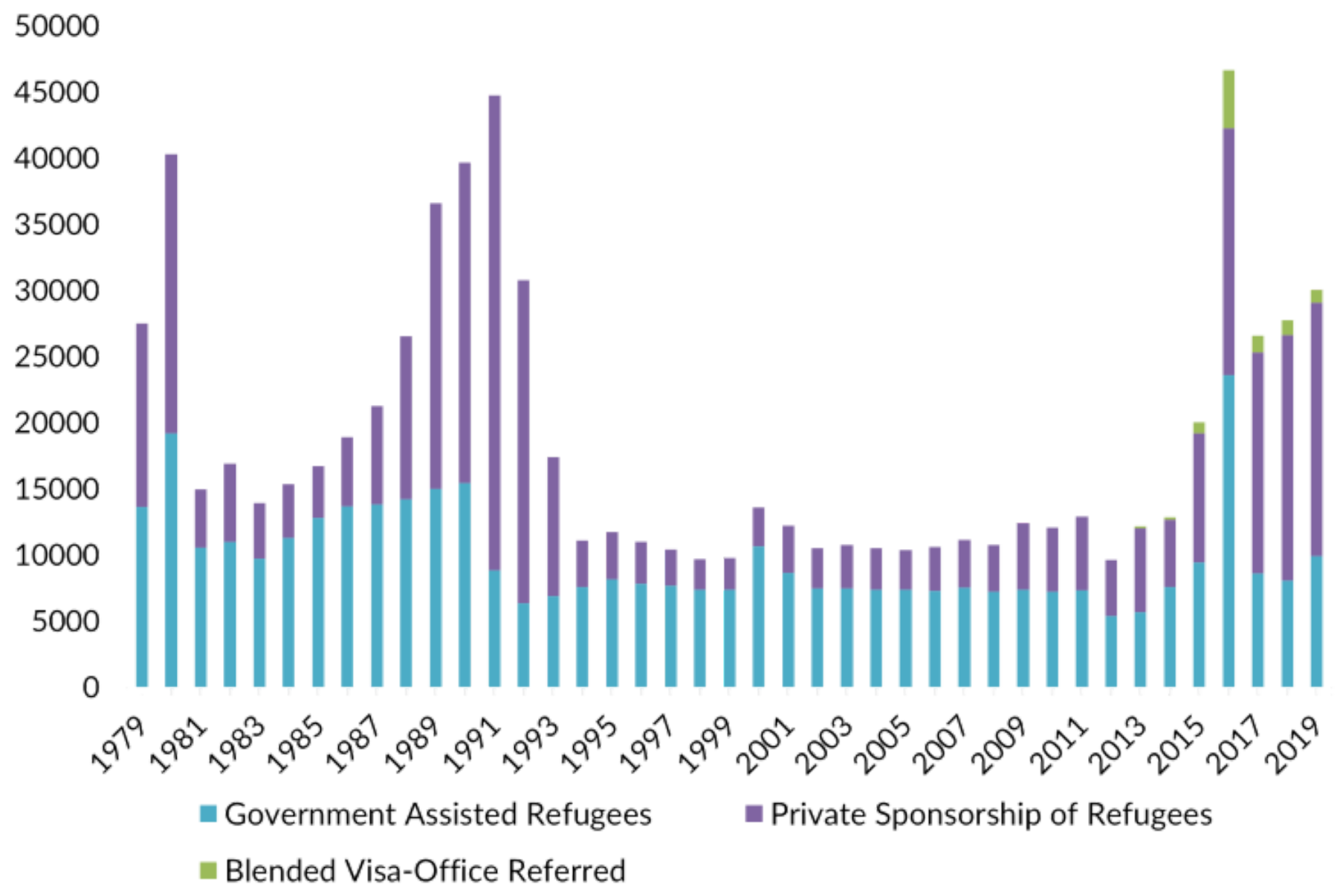

Note: The Blended Visa Office-Referred Refugees program was created in 2013. Sources: Data for 1979 from Barbara Treviranus and Michael Casasola, "Canada's Private Sponsorship of Refugees Program: A Practitioners Perspective of Its Past and Future," Journal of International Migration and Integration 4, no. 2 (2003): 177-202; data for 1980-2014 from Immigration, Refugees, and Citizenship Canada (IRCC), "Canada - Admissions of Permanent Residents by Immigration Category, 1980 - Q2 2016," last updated December 1, 2016, available online; data for 2015-19 from IRCC, 2020 Annual Report to Parliament on Immigration (Ottawa: IRCC), available online. 
At times, private sponsorship has far outstripped government resettlement. For instance, in 1991 four times as many refugees were resettled in Canada through private sponsorship than through the government channel. In 2019, more than 19,100 refugees were resettled via the PSR program-nearly as twice as many as the approximately 10,000 refugees resettled by the government.

\section{Figure 2. Process for Resettlement of Refugees to Canada}

Government Assisted

Refugee (GAR) Program:

- UNHCR proposes candidate for resettlement

- Canadian government decides whether to accept referral

Private Sponsorship of Refugees (PSR) Program: Sponsorship group submits application for assessment to Canadian government
If accepted for processing

Application Processed by Visa Office

Decision to accept or refuse application is based on meeting the legal requirements for humanitarian migration and not contravening any inadmissibility factors for migration to Canada

Source: Author's compilation based on current immigration law and policy.

Canadian law has relatively few immigration pathways for adult relatives-for example, there is no program to sponsor adult siblings - so Canadians with family members in refugee situations often use refugee sponsorship rather than a family reunification pathway to reunite with their extended family.

\section{Legal Requirements for Sponsorship and Resettlement}

Canada's immigration laws define who can be sponsored or selected for resettlement; there is no process by which individuals can seek asylum at consulates or embassies overseas. In the government-assisted and blended programs, refugees are referred by a recognized organization, which typically is UNHCR. In the private sponsorship program, groups decide whom they want to sponsor and apply to a government office in Canada, which ensures they meet the requirements for sponsorship, including the group's financial capacity to support the refugee and whether it has reached its cap for sponsorships or the refugee been through a status determination process. If approved, the file is then sent to an overseas visa office for processing, which includes health and security checks of the refugee.

Sponsorship Agreement Holders

Eligibility for sponsorship in the PSR program varies depending on who is submitting the sponsorship. In Canada, most refugee sponsorships are submitted by Sponsorship Agreement 
Holders (SAH), which are organizations with formal agreements with the government for repeat sponsorships. As of mid-2021, there were more than 100 SAHs. Many are affiliated with religious groups, but others are also nonreligious and community-based or focused on supporting certain ethnic groups. These organizations can submit sponsorship applications for anyone they believe will qualify under the PSR program, however the government sets limits on the number of applications individual SAHs can submit each year, based in part on their experience and past performance with resettlement.

\section{The Group of Five or Community Sponsor: Ad-Hoc Sponsorship}

It is also possible for small groups of Canadians who want to support specific refugees to do so with what is called a Group of Five sponsorship, which must be submitted by at least five members. Community organizations that are not backed by an SAH also can do so through the Community Sponsor channel. However, these approaches are subject to more stringent requirements. As part of their sponsorship application, they must include proof of a completed Refugee Status Determination (RSD) assessment showing the individual proposed for sponsorship has been recognized as a refugee by another country or UNHCR (see Table 2). There are no limits on the number of applications that can be submitted by groups using these ad hoc programs.

\section{Table 2. Requirements for Private Sponsorship Applications}

\begin{tabular}{|c|c|c|}
\hline & Sponsorship Agreement Holder (SAH) & $\begin{array}{l}\text { Ad hoc Groups: Group of Five or } \\
\text { Community Sponsor }\end{array}$ \\
\hline Capacity to Support? & $\begin{array}{l}\text { SAHs have agreements for a certain } \\
\text { number of sponsorships and manage } \\
\text { capacity to provide support }\end{array}$ & $\begin{array}{r}\text { Groups must demonstrate capacity to } \\
\text { meet specific financial requirements } \\
\text { indexed to the size of the family }\end{array}$ \\
\hline $\begin{array}{l}\text { Refugee Status } \\
\text { Determination? }\end{array}$ & No proof of refugee status required & $\begin{array}{r}\text { Required to show individuals being } \\
\text { sponsored have been recognized as } \\
\text { refugees by another country or UNHCR }\end{array}$ \\
\hline Numeric Limits? & $\begin{array}{r}\text { Each } \mathrm{SAH} \text { has a limited number of annual } \\
\text { resettlement spaces and must choose } \\
\text { whom they will submit }\end{array}$ & $\begin{array}{l}\text { No limit on the number of sponsorship } \\
\text { applications that can be submitted by } \\
\text { Community groups or Groups of Five }\end{array}$ \\
\hline
\end{tabular}

Note: Refugee Status Determination requirements do not apply in Quebec because the provincial government sets its own rules for sponsorship.

Source: Author's compilation based on current immigration law and policy.

The proportion of applications submitted by Groups of Five or Community Sponsors has changed over time (see Table 3). Before more stringent regulations on these applications were introduced in 2012, more than 40 percent of all refugees admitted in the PSR program were supported by such groups. This number dropped to 10 percent in 2016 but has since increased.

Table 3. Admissions of Privately Sponsored Refugees to Canada by Type of Sponsoring Group, 2010-19 


\begin{tabular}{|r|r|r|r|r|r|}
\hline & $\begin{array}{c}\text { All Privately } \\
\text { Sponsored } \\
\text { Refugees }\end{array}$ & $\begin{array}{c}\text { Sponsorship } \\
\text { Agreement Holder }\end{array}$ & Group of Five & $\begin{array}{c}\text { Community } \\
\text { Sponsorship }\end{array}$ & $\begin{array}{c}\text { Share as Group of } \\
\text { Five or Community } \\
\text { Sponsorship (\%) }\end{array}$ \\
\hline 2010 & 4,820 & 2,610 & 2,005 & 195 & 225 \\
\hline 2011 & 5,600 & 3,290 & 2,085 & 95 & $46 \%$ \\
\hline 2012 & 4,375 & 2,960 & 1,300 & 135 & $41 \%$ \\
\hline 2013 & 6,460 & 4,440 & 1,825 & 180 & $32 \%$ \\
\hline 2014 & 4,590 & 3,620 & 770 & 170 & $30 \%$ \\
\hline 2015 & 9,340 & 8,250 & 885 & 200 & $21 \%$ \\
\hline 2016 & 18,360 & 16,445 & 1,690 & 245 & $11 \%$ \\
\hline 2017 & 16,700 & 14,275 & 2,155 & 925 & $10 \%$ \\
\hline 2018 & 18,570 & 12,955 & 4,675 & 525 & $14 \%$ \\
\hline 2019 & 19,145 & 13,330 & 5,285 & & $30 \%$ \\
\hline
\end{tabular}

Note: Results are rounded to the nearest five digits and non-zero counts are suppressed. Annual totals may be slightly larger than the sums because the type of sponsorship was not indicated for a small number of cases (fewer than 1 percent).

Source: Data provided to the author by IRCC.

\section{Financial Requirements for Sponsorship}

In order to sponsor a refugee, organizations must demonstrate their capacity to provide basic assistance such as accommodation, food, and help to find a job, usually for one year after arrival. To ensure this requirement is met, the government requires specific levels of funds be guaranteed for each sponsorship, depending on the size of the family. In recent years, the government has increased surveillance of sponsorship groups to ensure that requirements are being met.

\section{Refugee Status Determination Requirements}

The requirement that ad hoc groups provide proof that an individual has been granted refugee status was implemented in 2012. When introduced, the government argued the determination was needed to counteract low approval rates, large inventories, and long processing times, since many poorquality applications had been submitted through the PSR program. However, this requirement added a barrier for applicants, as determination of refugee status is not always available.

Canadian sponsors and the organizations that assist them have attested that the availability of RSD documents varies depending on where refugees reside, creating a patchwork approach. For example, one man who regularly sponsored Eritrean refugees through the Group of Five program explained to the author in 2019 that he could not sponsor Eritreans residing in Israel because they could not obtain proof of refugee status from the Israeli government or UNHCR. However, Eritrean refugees in Sudan were able to obtain RSD documents, which made it easy for them to be sponsored. Another regular sponsor said his mosque used the Community Sponsor program to assist refugees with RSD documents in Kenya and Sudan, however it had to work with established SAHs to sponsor Syrians living in Jordan and Lebanon because they could not obtain proof of refugee status.

The Canadian Council for Refugees, an umbrella nongovernmental organization, has urged the government to remove the RSD requirement for Groups of Five and Community Sponsors. In order to meet its target of resettling 25,000 Syrian refugees and facilitate sponsorship among ad hoc 
groups wanting to support individuals who could not obtain RSD documents, the government temporarily waived the requirement for Syrians and Iraqis from 2015 to 2017. However, most Syrians and Iraqis-among many others-continue to be unable to obtain documentation asserting their refugee status in their countries of first asylum. The government has resisted the call to end the RSD requirement permanently, claiming it is necessary to ensure the system properly assists refugees whom it intends to target.

\section{Caps on New Sponsorships}

Since 2012, the Canadian government has capped the number of refugees that SAHs can sponsor each year. The government argued it needed to control the number of new applications because sponsorship groups had submitted more applications than the government planned to process each year, leading to backlogs and longer processing times. The caps were introduced in tandem with the RSD requirement to better match government operational capacity with the number of applications received on an annual basis.

At first, caps were based on specific origin regions, and SAHs were prevented from submitting new applications entirely for individuals from some parts of the world. After 2016, the caps shifted to a global limit on the number of new applications. The sponsorship allocation for 2021 was set at 12,500 refugees, with the allocations divided up among all SAHs.

Although cap space has increased and higher numbers of privately sponsored refugees have arrived in recent years, organizations remain constrained in the number of applications they can submit. Some groups operate on a first-in, first-out procedure, while others randomly select who will be sponsored each year. When SAHs reach their limits, individuals who want to sponsor refugees must use the Group of Five or Community Sponsor programs to submit applications.

Sponsorship caps have been criticized by refugee-rights advocates. In Quebec, significant limits on new sponsorship applications have become a sensitive political issue. Elsewhere, an overall increase in the number of refugees admitted via the PSR program since 2015 has reduced the criticism that followed the caps' introduction. However, limits on the number of applications that SAHs can submit can constrain or delay groups that would like to sponsor refugees.

\section{A Distinct Approach in Quebec}

Unlike the rest of the country, where the federal government has jurisdiction, the provincial government of Quebec controls the sponsorship of refugees within its borders. The province's autonomy is rooted in its distinctiveness as the only francophone-majority province in Canada and its increased control over immigration more generally. From 2015 to 2019, 24 percent of all sponsored refugees arriving in Canada went to Quebec.

Quebec has no RSD requirement for submitting applications to sponsor refugees, but the provincial government has frequently closed the program to new submissions, only to open it later with strict limits on the number of submissions that will be received. Financial requirements for sponsoring refugees in Quebec are similar to those elsewhere in Canada.

\section{Integration of Refugees and Global Private Sponsorship Programs}

Since refugees who arrive through private sponsorship are often identified by name and usually have a pre-existing tie to their sponsor, they generally adapt more quickly to Canada than those who arrive through the government-assisted pathway. However, the programs target different types of refugees: 
among the criteria that UNHCR uses for identifying refugees through Canada's GAR and BVOR programs are vulnerability standards for individuals most needing a third-country solution.

In contrast, requirements such as sponsors' ability to provide assistance, RSD for ad hoc sponsorships, and limits on the number of sponsorships for SAHs encourages sponsors to assist refugees who will adapt quickly. Moreover, when they arrive in Canada, privately sponsored refugees are more likely to speak English or French and have more education, which likely contributes to findings that they are quicker to find employment. In addition, they tend to have been displaced for shorter periods of time than refugees resettled via the government path, suggesting less exposure to trauma. Since the sponsoring group must provide for the refugee's financial needs, there is also an incentive to quickly find them employment and economic independence.

More generally, Canada's private sponsorship program has become an important component of UNHCR's strategy to increase durable solutions for refugees through complementary pathways. Community sponsorship is seen as a promising option for countries to assist more refugees and Canada's system is promoted as a model for others by the UNHCR-funded Global Refugee Sponsorship Initiative.

At the same time, there is a strong emphasis among refugee advocates that sponsorship programs complement government-assisted programs for vulnerable refugees identified by UNHCR, not replace them. This is particularly true given Canada's requirements for RSD in ad hoc sponsorships and caps on sponsor organizations that restrict who can be sponsored in this program. As new countries explore private sponsorship or other complementary pathways, they may also consider how such programs are designed, who is included in them, and how to continue promoting pathways that respond to the global call to assist in resettling vulnerable refugees.

\section{Sources}

Boyd, Monica and Shawn Perron. 2020. Private and Government Sponsorships: Occupational and Earnings Outcomes for Vietnamese, Laotian and Cambodian Refugees. Canadian Diversity 17 (2): 70-76. Available online.

Cameron, Geoffrey. 2021. Send Them Here: Religion, Politics, and Refugee Resettlement in North America. Montreal: McGill-Queen's University Press.

Canadian Council for Refugees. 2013. Limitations on G-5 Sponsorship. Updated November 2013. Available online.

---. 2017. Private Sponsorship of Refugees in 2017. Updated January 2017. Available online.

Coker, Bolu. 2017. A Half Welcome: Delays, Limits, and Inequities in Canadian Refugee Sponsorship. Ottawa: Citizens for Public Justice. Available online.

Employment and Immigration Canada. 1982. Indochinese Refugees: The Canadian Response, 1979 and 1980. Ottawa: Employment and Immigration Canada. Available online.

Fratzke, Susan, Lena Kainz, Hanne Beirens, Emma Dorst, and Jessica Bolter. 2019. Refugee Sponsorship Programmes: A Global State of Play and Opportunities for Investment. Brussels: Migration Policy Institute Europe. Available online.

Garnier, Adèle and Shauna Labman. 2020. Why Québec's Refugee Sponsorship Suspension Is So Misguided. The Conversation, November 22, 2020. Available online. 
Garnier, Adèle, Liliana Lyra Jubilut, and Kristin Bergtora Sandvik. 2018. Refugee Resettlement: Power, Politics, and Humanitarian Governance. New York: Berghahn Books.

Girard, Raphael. 2005. Designated Classes: A Regulatory Device to Target Humanitarian Resettlement Programs. Canadian Immigration Historical Society Bulletin 47: 2-5. Available online.

Government of Canada. 1976. Immigration Act, 1976-77. Available online.

---. 2018. UNHCR Resettlement Handbook: Country Chapter - Canada. N.p.: UN High Commissioner for Refugees (UNHCR). Available online.

---. 2021. Immigration and Refugee Protection Regulations (SOR/2002-227). Updated May 19, 2021. Available online.

Global Refugee Sponsorship Initiative (GRSI). N.d. Building Blocks of Community Sponsorship: Guidebook and Planning Tools Based on Canada's Model. Accessed June 8, 2021. Available online.

Houle, René. 2019. Results from the 2016 Census: Syrian Refugees Who Resettled in Canada in 2015 and 2016. Ottawa: Statistics Canada. Available online.

Hyndman, Jennifer, William Payne, and Shauna Jimenez. 2016. The State of Private Refugee Sponsorship in Canada: Trends, Issues, and Impacts. Policy brief, York University, Centre for Refugee Studies, Toronto, December 2016. Available online.

Immigration, Refugees, and Citizenship Canada (IRCC). 2013. Referrals from the UNHCR and Other Authorized Organizations. Updated February 25, 2013. Available online.

---. 2016. Canada - Admissions of Permanent Residents by Immigration Category, 1980 - Q2 2016. Last updated December 1, 2016. Available online.

---. 2020. Assessment of Sponsorship (PSR Program). Updated February 10, 2020. Available online.

---. 2020. Eligible Sponsorship Types. Updated February 10, 2020. Available online.

---. 2020. Receipt and Intake of Application (GAR Program). Updated February 10, 2020. Available online.

---. 2020. Who Decides If a Refugee Can Be Sponsored and Resettled? Updated January 30, 2020. Available online.

---. 2021. Global Cap for Sponsorship Agreement Holders. Updated February 12, 2021. Available online.

---. 2021. Guide 2200 - Groups of Five to Privately Sponsor Refugees. Updated March 1, 2021. Available online.

---. 2021. Guide 2201 - Community Sponsors to Privately Sponsor Refugees. Updated March 1, 2021. Available online.

---. 2021. Guide 5413 - Sponsorship Agreement Holders to Privately Sponsor Refugees. Updated March 1, 2021. Available online. 
---. 2021. Sponsorship Agreement Holders: How to Sponsor a Refugee. Updated March 31, 2021. Available online.

Labman, Shauna. 2016. Private Sponsorship: Complementary or Conflicting Interests? Refuge: Canada's Journal on Refugees 32 (2): 67-80. Available online.

---. 2019. Crossing Law's Border: Canada's Refugee Resettlement Program. Vancouver: University of British Columbia Press.

Labman, Shauna and Jennifer Hyndman. 2019. BVOR Briefing Note. Policy brief, York University, Centre for Refugee Studies, Toronto, May 2019. Available online.

Labman, Shauna and Madison Pearlman. 2018. Blending, Bargaining, and Burden-Sharing: Canada's Resettlement Programs. Journal of International Migration and Integration 19 (2): 439-49.

Lehr, Sabine and Brian Dyck. 2020. 'Naming' Refugees in the Canadian Private Sponsorship of Refugees Program: Diverse Intentions and Consequences. In Strangers to Neighbours: Refugee Sponsorship in Context, eds. Shauna Labman and Geoffrey Cameron. Montreal: McGill-Queen's University Press.

Ministère de l'Immigration, de la Francisation et de l'Intégration. 2020. 2015-2019 Tableaux de l'immigration permanente au Québec. Montreal: Government of Quebec. Available online.

Molloy, Michael J., Peter Duschinsky, Kurt F. Jensen, and Robert J. Shalka. 2017. Running on Empty: Canada and the Indochinese Refugees, 1975-198o. Montreal: McGill-Queen's University Press.

Morris, Stéfanie, Patti Tamara Lenard, and Stacey Haugen. 2020. Refugee Sponsorship and Family Reunification. Journal of Refugee Studies: feaa062.

Treviranus, Barbara and Michael Casasola. 2003. Canada's Private Sponsorship of Refugees Program: A Practitioners Perspective of Its Past and Future. Journal of International Migration and Integration/Revue de l'integration et de la migration internationale 4 (2): 177-202.

UN High Commissioner for Refugees (UNHCR). 2011. UNHCR Resettlement Handbook. Geneva: UNHCR. Available online.

---. 2019. Complementary Pathways for Admission of Refugees to Third Countries: Key Considerations. Geneva: UNHCR. Available online.

IF YOU HAVE QUESTIONS OR COMMENTS ABOUT THIS ARTICLE, CONTACT US AT Source@MigrationPolicy.org

Source URL: https://www.migrationpolicy.org/article/canada-private-sponsorship-model-refugee-resettlement 